\title{
EGFR and PTEN Gene Mutation Status in Glioblastoma Patients and their Prognostic Impact on Patient's Survival
}

Sajad Hussain Arif ${ }^{1 \Psi^{*}}$, Arshad A. Pandith ${ }^{2 \Psi}$, Abdul Rashid Bhat $^{1}$, Altaf Umar Ramzan ${ }^{1}$, Nayil Khursheed Malik ${ }^{1}$, Sarabjit S. Chibber ${ }^{1}$, Abrar A. Wani ${ }^{1}$, Rehana Tabasum $^{3}$ and Altaf Kirmani ${ }^{1}$

Contributed equally

${ }^{1}$ Department of Neurosurgery, Sher-I-Kashmir Institute of Medical Sciences, Soura, Srinagar-190011, Kashmir, India

${ }^{2}$ Advanced Centre for Human Genetics, Sher-I-Kashmir Institute of Medical Sciences, Soura, Srinagar-190011, Kashmir, India

${ }^{3}$ Department of Pharmacology, Sher-I-Kashmir Institute of Medical Sciences, Soura, Srinagar-190018, Kashmir, India

*Corresponding author: Sajad Hussain Arif, Department of Neurosurgery, Sher-I-Kashmir Institute of Medical Sciences, Soura, Srinagar 190011, Jammu and Kashmir, India, Tel: +91-194-240 34; E-mail: sajadarif.neuro@gmail.com

Received date: January 02, 2015; Accepted date: March 16 2015; Published date: March 24, 2015

Copyright: () 2015 Arif SH, et al. This is an open-access article distributed under the terms of the Creative Commons Attribution License, which permits unrestricted use, distribution, and reproduction in any medium, provided the original author and source are credited.

\begin{abstract}
Glioblastoma multiforme (GBM) is the most aggressive form of glioma. Genetic analysis of GBM tumorigenesis has identified several alterations in particular EGFR and PTEN genes. The purpose of the present study was to analyze the frequency and distribution of EGFR/PTEN mutations in GBM and to determine their relationship with different clinicopathological characteristics.
\end{abstract}

The paired tumor and adjacent normal tissue specimens of 40 consecutive patients with GBM were examined and DNA preparations were evaluated for the occurrence of EGFR/PTEN gene mutations by PCR-SCCP and DNA sequencing.

In total, 20 of 40 (50\%) GBM tumours had mutation of either an EGFR or PTEN. EGFR gene mutation was present in $13(32.5 \%)$ and PTEN gene mutations in 07 of $40(17.5 \%)$ patients. Both EGFR/PTEN mutations were found in 03 of 40 samples (7.5\%). The samples which showed EGFR mutations but were negative for PTEN were detected in 10 of $40(25 \%)$ patients (EGFR+ve/PTEN-ve). The samples with PTEN +ve/EGFR -ve were present in 04 of $40(10 \%)$ patients. Median PFS and Median OS was better in patients with EGFR +ve/PTEN -ve (p>0.05).

EGFR and PTEN gene mutations exist in our population with GBM and play a significant role in its development with better survival for patients for EGFR+ve/PTE -ve mutation status.

Keywords: Glioblastoma multiforme; Mutations; Overall survival; DNA sequencing

\section{Introduction}

Glioblastoma multiforme (GBM) is the most common primary brain tumor in adults [1]. Although GBM occurs in patients of all ages, the incidence is highest in the elderly, and GBM is slightly more common in whites and men [1,2]. Astrocytic tumors are the most common glial neoplasms, with an annual incidence of 3-4/100,000 inhabitants, and approximately $80 \%$ are glioblastomas [3]. In India the incidence is about 3/100,000 population [4]. In Kashmir (North India), among the brain tumors glioma $(60 \%)$ is the commonest in which GBM is the most common followed by diffuse and anaplastic astrocytoma [5]. Glioblastomas remain one of the most lethal forms of cancers with a median survival of 10 to 12 months [6]. Unlike most other types of cancer, glioblastomas rarely metastasize; rather, they induce death through striking resistance to current therapies and invasion into normal brain tissues [7]. Recent therapies in GBM have focused on the inhibition of tyrosine kinases and associated growth factor pathways. Over activity of the epidermal growth factor receptor $(E G F R)$ pathway is associated with resistance to treatment with $\mathrm{RT}$ and chemotherapy $[8,9]$. Therefore, combining targeted $E G F R$ therapy with RT or chemotherapy may increase the effectiveness of treatment.

It has been suggested that genetic alterations of certain genes are critical events behind the pathogenesis of gliomas. The EGFR is a receptor tyrosine kinase that regulates fundamental processes of cell growth and differentiation. Mechanisms for oncogenic conversion of $E G F R$ in cancer include $E G F R$ gene amplification, structural rearrangements of the receptor, overexpression of epidermal growth factor $(E G F)$-family ligands by tumor cells and/or surrounding stroma, and activating mutations in the EGFR kinase domain [10]. $E G F R$ gene amplification ( $>40 \%$ of cases) and over-expression $(>60 \%$ of cases) are a striking feature of GBM. The most common $E G F R$ mutant is named EGFRvIII (EGFR type III, EGFRvIII, del2-7, $\triangle E G F R$ ) [11]. Phosphatase and tensin homolog $(P T E N)$, a tumor suppressor gene is a dual-specificity phosphatase. In general, PTEN negatively regulates the anti-apoptotic action of akt phosphorylation. In addition, other types of cancer and the inherited predisposition to cancer, Cowden disease, are associated with PTEN mutations [12]. It has been reported that mutations of $P T E N$ have been implicated in the malignant progression of astrocytic gliomas, as these alterations are most frequently observed in GBM and very rare in the lower grade astrocytoma [13]. 
Cancer is a major disease burden worldwide but there are marked geographical variations in incidence and frequency overall and at specific organ sites. The valley of Kashmir situated at an altitude of about $1800 \mathrm{~m}$ to $2400 \mathrm{~m}$ above sea level is among one of the provincial territories of India. Kashmir, regarded worldwide as paradise on earth, with over 5 million populations is heavily burdened with cancer. This mountain locked region presents a strikingly different pattern of distribution of cancers not only from India but from most parts of world. So this study aims at finding the mutations, if any, in the hotspot regions of both EGFR and PTEN genes and their correlation in GBM patients owing to the fact that there is no data on genetic alterations in GBM available either in our population. It is the first initiative to study the recurrence and overall survival of the GBM patients in light of EGFR and PTEN mutations.

\section{Materials and Methods}

\section{Patients}

A total of 40 histologically confirmed, previously untreated GBM patients attending Department of Neurosurgery of Sher-I-Kashmir Institute of Medical Sciences (SKIMS), Srinagar were included in this study. The diagnosis of GBM was considered on the histopathological examination. Blood samples were available for 15 cases for ruling out the germ line mutations. A written pre informed consent was obtained from all cases. Demographic and clinicopathological characteristics of each patient were recorded. This study was approved by the Ethical committee of the SKIMS.

\section{Sample collection/storage}

$05 \mathrm{ml}$ of peripheral blood was obtained from each subject in EDTA containing vials $(200 \mu \mathrm{l}$ of $0.5 \mathrm{M}, \mathrm{pH}=8.0)$ and stored at $-20^{\circ} \mathrm{C}$ till use. The surgically resected tissue samples taken through stereotactic/open biopsy of GBM tumors and adjacent normal tissues were collected directly into sterile vials containing chilled PBS $(\mathrm{pH}=7.2)$ and frozen at $-70^{\circ} \mathrm{C}$ for molecular investigations. Histopathologically confirmed GBM tissues and corresponding normal tissues were used for mutational analysis of EGFR and PTENgene.

\section{Extraction and Quantitation of genomic DNA}

DNA was extracted from the tissues by Phenol-Chloroform method and by Qiagen DNA extraction kit (Zymo Research Corporation, USA) while salting out method was used for the extraction of DNA from blood samples. The concentration of the DNA obtained was measured in a spectrophotometer at $260 \mathrm{~nm}$ wavelength by using the formula: DNA $\mu \mathrm{g} / \mathrm{ml}=\mathrm{A}_{260} \times 50 \times$ dilution factor. The purity of DNA was checked by using $\mathrm{A}_{260} / \mathrm{A}_{280}$ ratio. The quality of the DNA obtained from the tissue specimens and blood samples was analyzed on $1 \%$ agarose gel.

\section{PCR amplification of EGFR and PTEN genes}

Four hot spot coding exons $(18,19,20$ and 21) of EGFR gene and three coding exons of PTEN family of genes were amplified (exons 5, 7 and 8) using previously described specific primers (Table 1). PCR amplification was carried out in a $50 \mu \mathrm{L}$ volume container with $50 \mathrm{ng}$ of genomic DNA, 1XPCR buffer containing $15 \mathrm{mM} \mathrm{MgCl}_{2}, 100 \mu \mathrm{M}$ each of dATP, dGTP, dTTP, dCTP, and $1.5 \mathrm{U}$ of Taq DNA polymerase (Biotools; Madrid, Spain), and $1 \mu \mathrm{M}$ of forward and reverse primers (Genescript; Piscataway, NJ, USA). The thermal conditions and product sizes of each exon for both EGFR and PTENgene are given in Table 1 . The PCR products were run on $2 \%$ agarose gel and analyzed under an ultraviolet illuminator. The single-strand conformation polymorphism (SSCP) analysis of the amplicons of exons 18, 19, 20 and 21 of EGFR gene and three coding exons 5, 7, and 8 of PTEN family of genes was performed on $6 \%$ non-denaturing polyacrylamide gel (PAGE) utilizing nonradioactive silver staining. The purified PCR amplicons of the tumor samples showing mobility shift on SSCP analysis and randomly chosen normal samples were used for direct DNA sequencing, using the automated DNA sequencer ABI Prism 310 Genetic Analyzer (Macrogen Korea).

\section{Statistical analysis}

Statistical analysis was performed by using SPSS 16.0 software. Fisher's exact test, Chi Square test for homogeneity of proportions and Odds ratio was used wherever applicable. Statistical significance was considered when $\mathrm{P}<0.05$. Kaplan Meier curve for Progression free survival was drawn by using SPSS software. Survival time was calculated from the date of first surgery to the date of death or date of last contact if lost to follow up evaluation or Jan 31, 2011. Follow up ranged from 6 months to a maximum of 25 months. Progression-free survival was defined as the time from first surgery to first evidence of tumor progression on CT or MRI or to death [14]. Tumor progression was defined as the appearance of new lesions, an increase in tumor extension by $25 \%$ on CT or MRI, a worsening in the clinical/ neurological condition, or an increased need for corticosteroids [15].

\section{Results}

The present study comprised of 40 histologically confirmed cases of GBM. There were $28(70 \%)$ males and $12(30 \%)$ females with a male female ratio of 2.3:1. The mean age of the patients was $52.9 \pm 12.4$ years. The patients ranged in age from 26-70 years (Table 2). Majority of the patients $27(67.5 \%)$ had Karnofsky Performance Score of $>70$ and $13(32.5 \%)$ had $\leq 70$. Mean KPS was $78.2 \pm 9.8$. Majority of the tumors $19(47.5 \%)$ were located on the Left side and 17 (42.5\%) were present on the Right side. Midline tumors were observed in only 04 $(10 \%)$ of patients. Majority of the tumors $12(30 \%)$ involved more than one lobe. Among the single lobe involvement, temporal lobe 11 (27.5\%) was the commonest. Other sites involved were frontal, parietal, midline; occipital and thalamic. Most of the patients 22 (55\%) were subjected to gross total resection while as 13 (32.5\%) were subjected to sub total resection and only biopsy was performed in 05 (12.5\%) patients. All the patients were put on Gefitinib $250-500 \mathrm{mg} /$ day.

Overall mutations in exon 18, 19, 20 and 21 of $E G F R$ identified in this study aggregated to $32.5 \%$ ( 13 of 40 ). In all there were 13 missence mutations, seven were $\mathrm{C}>\mathrm{A}$ transversions and six were $\mathrm{A}>\mathrm{T}$ transversions. We detected two different single-nucleotide substitutions in 13 of the 40 GBM patients (Table 3). Codon 691 contained $21.42 \%(3 / 14)$, codon 737 comprised of $46.15 \%(6 / 13)$ mutations while as codon 742 contained $30.76 \%(4 / 13)$ mutations. In $P T E N$ gene the present study looked for mutations in exon 5, 7 and 8 which are reported to be the hot spot exons. In PTEN gene we found mutations in 07 of 40 (17.5\%) GBM patients. In all we detected 07 missence mutations in exon 5 and 7 but could not detect any mutations in exon 8 . The mutations comprised of only transitions ( 3 $\mathrm{A}>\mathrm{G}$ and $4 \mathrm{G}>\mathrm{A}$ ) involving codon 449, 384 and 628. Codon 449 and 384 contained $28.57 \%$ ( 2 of 7 ) mutations each while as codon 628 comprised of $42.85 \%$ ( 3 of 7 ) mutations (Table 3 ). 
Citation: $\quad$ Arif SH, Pandith AA, Bhat AR, Ramzan AU, Malik Nk,et al. (2015) EGFR and PTEN Gene Mutation Status in Glioblastoma Patients and their Prognostic Impact on Patient's Survival. J Carcinog Mutagen 6: 218. doi:10.4172/2157-2518.1000218

Page 3 of 7

\begin{tabular}{|c|c|c|c|c|}
\hline Gene & $\begin{array}{l}\text { Exo } \\
n\end{array}$ & Primer sequence & $\begin{array}{l}\mathrm{Tm} \\
\text { (C) }\end{array}$ & $\begin{array}{l}\text { Product } \\
\text { size (bp) }\end{array}$ \\
\hline \multirow[t]{4}{*}{ EGFR } & 18 & $\begin{array}{l}\text { F-5'CCAAATGAGCTGGCAAGTG 3' } \\
\text { R-5'TCCCAAACACTCAGTGAAACAAA } \\
3^{\prime}\end{array}$ & 58 & 397 \\
\hline & 19 & $\begin{array}{l}\text { F-5'CCCAGTGTCCCTCACCTTC 3' } \\
\text { R-5'GCAGGGTCTAGAGCAGAGCA 3' }\end{array}$ & 62 & 306 \\
\hline & 20 & $\begin{array}{l}\text { F-5'CATTCATGCGTCTTCACCTG 3' } \\
\text { R- 5'CATATCCCCATGGCAAACTC } 3^{\prime}\end{array}$ & 58 & 377 \\
\hline & 21 & $\begin{array}{l}\text { F-5'GCTCAGAGCCTGGCATGAA 3' } \\
\text { R-5'CATCCTCCСCTGCATGTGT 3' }\end{array}$ & 62 & 348 \\
\hline \multirow[t]{4}{*}{ PTEN } & 5 & $\begin{array}{l}\text { F-5'GCAACATTTCTAAAGTTACCTACT } \\
\text { TG } 3^{\prime} \\
\text { R-5'CCAATAAATTCTCAGATCCAGG } 3^{\prime}\end{array}$ & 50 & 378 \\
\hline & 7 & $\begin{array}{l}\text { F-5'TGGTATGTATTTAACCATGC 3' } \\
\text { R-5' CCTTATTTTGATATTTCTCCC 3' }\end{array}$ & 57 & 231 \\
\hline & $8 / 1$ & $\begin{array}{l}\text { F-5'TGCAAATGTTTAACATAGGTGA 3' } \\
\text { R-5'CCTTGTCATTATCTGCACGC 3' }\end{array}$ & 55 & 246 \\
\hline & $8 / 2$ & $\begin{array}{l}\text { F-5 GGAAGTCTATGTGATCAAGA 3' } \\
\text { R-5' CGTAAACACTGCTTCGAAATA 3' }\end{array}$ & 53 & 286 \\
\hline
\end{tabular}

Table 1: Primer sequences and annealing temperatures for sequencing of EGFR and PTENgenes.

\begin{tabular}{|c|c|c|c|c|c|c|c|}
\hline \multirow[t]{2}{*}{ Age (years) } & \multicolumn{2}{|c|}{ Male } & \multicolumn{2}{|c|}{ Female } & \multicolumn{2}{|c|}{ Total } & \multirow[t]{2}{*}{$P$ value } \\
\hline & $\mathrm{N}$ & $\%$ & $\mathrm{n}$ & $\%$ & $\mathrm{n}$ & $\%$ & \\
\hline 30 & 4 & 14.3 & 0 & 0.0 & 4 & 10.0 & \multirow[t]{6}{*}{0.135} \\
\hline 31 to 40 & 2 & 7.1 & 1 & 8.3 & 3 & 7.5 & \\
\hline 41 to 50 & 7 & 25.0 & 3 & 25.0 & 10 & 25.0 & \\
\hline 51 to 60 & 8 & 28.6 & 2 & 16.7 & 10 & 25.0 & \\
\hline$>60$ & 7 & 25.0 & 6 & 50.0 & 13 & 32.5 & \\
\hline Total & 28 & 70.0 & 12 & 30.0 & 40 & 100.0 & \\
\hline mean $\pm S D$ & \multicolumn{2}{|c|}{$50.9 \pm 12.8$} & \multicolumn{2}{|c|}{$57.4 \pm 10.7$} & \multicolumn{2}{|c|}{$52.9 \pm 12.4$} & \\
\hline
\end{tabular}

Table 2: Age and gender distribution of the patients.

The overall frequencies of EGFR and PTEN mutations in GBM patients are shown in Table 4. In total, 20 of 40 (50\%) GBM tumours studied had mutation of either an EGFR or PTEN. EGFR mutation was present in 13 of $40(32.5 \%)$ patients and PTEN gene mutations in 07 of $40(17.5 \%)$ patients. Both EGFR and PTEN mutations were found in 03 samples (7.5\%). The samples which showed EGFR mutations but were negative for PTEN were detected in 10 of 40 (25\%) patients $(E G F R+\mathrm{ve} / P T E N$-ve). The samples which showed PTEN mutations but were absent in EGFR (PTEN +ve /EGFR-ve) were present in 04 $(10 \%)$ patients. No mutations were seen in both the genes $(E G F R /$ PTENboth -ve) in 23 patients (57.5\%) (Table 4).

\begin{tabular}{|c|c|c|c|c|c|c|}
\hline GENE & $\begin{array}{l}\text { Case } \\
\text { No. }\end{array}$ & Sex & $\begin{array}{l}\text { Age } \\
\text { (years) }\end{array}$ & Exon & $\begin{array}{l}\text { Nucleotide } \\
\text { Change }\end{array}$ & $\begin{array}{l}\text { Amino } \\
\text { Acid } \\
\text { Change }\end{array}$ \\
\hline \multirow[t]{13}{*}{ EGFR } & 1 & M & 62 & 19 & $742 C>A$ & Pro $>\mathrm{His}$ \\
\hline & 2 & M & 26 & 19 & $742 C>A$ & Pro $>\mathrm{His}$ \\
\hline & 3 & $M$ & 50 & 18 & $691 C>A$ & Pro $>$ Thr \\
\hline & 4 & $M$ & 45 & 19 & $737 \mathrm{~A}>\mathrm{T}$ & Pro $>$ Thr \\
\hline & 8 & $M$ & 65 & 20 & $737 \mathrm{~A}>\mathrm{T}$ & Lys>lle \\
\hline & 14 & $\mathrm{~F}$ & 62 & 21 & $742 \mathrm{C}>\mathrm{A}$ & Pro $>$ His \\
\hline & 17 & M & 35 & 21 & $742 C>A$ & Pro $>\mathrm{His}$ \\
\hline & 18 & $\mathrm{~F}$ & 60 & 20 & $737 A>T$ & Lys $>\| l e$ \\
\hline & 22 & M & 26 & 21 & $691 \mathrm{C}>\mathrm{A}$ & Pro $>\mathrm{Thr}$ \\
\hline & 24 & M & 45 & 20 & $737 A>T$ & Lys>lle \\
\hline & 28 & M & 60 & 20 & $737 A>T$ & Lys>lle \\
\hline & 34 & $\mathrm{~F}$ & 70 & 21 & $691 C>A$ & Pro $>T h r$ \\
\hline & 37 & M & 65 & 20 & $737 A>T$ & Lys $>\| l e$ \\
\hline \multirow[t]{7}{*}{ PTEN } & 1 & M & 62 & 5 & $449 \mathrm{G}>\mathrm{A}$ & D152N \\
\hline & 3 & M & 50 & 5 & $449 \mathrm{G}>\mathrm{A}$ & D152N \\
\hline & 6 & $\mathrm{~F}$ & 65 & 5 & $384 G>A$ & G128R \\
\hline & 10 & $\mathrm{~F}$ & 50 & 7 & $628 \mathrm{~A}>\mathrm{G}$ & $\mathrm{T} 211 \mathrm{~A}$ \\
\hline & 18 & $\mathrm{~F}$ & 60 & 7 & $628 \mathrm{~A}>\mathrm{G}$ & $\mathrm{T} 211 \mathrm{~A}$ \\
\hline & 26 & M & 58 & 7 & $628 \mathrm{~A}>\mathrm{G}$ & $\mathrm{T} 211 \mathrm{~A}$ \\
\hline & 30 & M & 57 & 5 & $384 G>A$ & G128R \\
\hline
\end{tabular}

Table 3: Genetic alterations in EGFR and PTEN genes in GBM patients.

\begin{tabular}{|l|l|l|}
\hline Mutations & No & Percentage \\
\hline EGFR Mutation & 13 & 32.5 \\
\hline PTEN Mutation & 7 & 17.5 \\
\hline EGFR/PTEN (Both +ve) & 3 & 7.5 \\
\hline EGFR +ve/PTEN -ve & 10 & 25 \\
\hline PTEN+ve/EGFR-ve & 4 & 10 \\
\hline EGFR-ve/PTEN-ve & 23 & 57.5 \\
\hline
\end{tabular}

Table 4: Distribution of patients as per the type of mutation.

Median Progression free survival (PFS) was $6(5,7)$ and Median Overall Survival (OS) was $15(12,18)$ months in patients who were $<60$ years of age compared to 14 months in patients $\geq 60$ years of age. Median Overall survival was better i.e., 15 months in patients with KPS $>70$ compared to 13 months in patients with KPS $\leq 70$ ( $\mathrm{p}>0.05)$. Median PFS was better i.e. 7 months in patients with gross total resection compared to patients who were subjected to subtotal 
resection (5 months) or Biopsy (3 months) and it was statistically significant. Median PFS and median OS was better (9 and 20 months) in patients who were $E G F R+\mathrm{ve} / P T E N$-ve as compared to patients with $P T E N+\mathrm{ve} / E G F R$-ve (6 and 13 months), EGFR+ve/PTEN+ve (6 and 13 months respectively) and EGFR-ve/PTEN-ve (6 and 14 months). The findings were statistically significant (Table 5).

\begin{tabular}{|c|c|c|c|c|c|}
\hline \multicolumn{2}{|l|}{ Factors } & \multicolumn{2}{|l|}{ PFS } & \multicolumn{2}{|l|}{ os } \\
\hline & & Months & Log rank $p$ & Months & Log rank $p$ \\
\hline \multirow[t]{2}{*}{ Age (yr) } & $<60$ & 6 & \multirow[t]{2}{*}{0.0339} & 15 & \multirow[t]{2}{*}{0.2125} \\
\hline & & 14 & & 14 & \\
\hline Karnofsky & $\leq 70$ & 6 & \multirow[t]{2}{*}{0.4584} & 13 & \multirow[t]{2}{*}{0.6207} \\
\hline $\begin{array}{l}\text { Performance } \\
\text { Score }\end{array}$ & $>70$ & 6 & & 15 & \\
\hline \multicolumn{2}{|c|}{ EGFR + ve/PTEN -ve } & 9 & \multirow[t]{4}{*}{0.0058} & 20 & \multirow[t]{4}{*}{0.0078} \\
\hline \multicolumn{2}{|c|}{$P T E N+v e / E G F R$-ve } & 6 & & 13 & \\
\hline \multicolumn{2}{|c|}{ EGFR/PTEN (Both +ve) } & 6 & & 9 & \\
\hline \multicolumn{2}{|c|}{ EGFR/PTEN (Both -ve) } & 6 & & 14 & \\
\hline \multirow[t]{3}{*}{ Procedure } & $\begin{array}{l}\text { Gross Total } \\
\text { Resection }\end{array}$ & 7 & \multirow[t]{3}{*}{0.0001} & 17 & \multirow[t]{3}{*}{0.1112} \\
\hline & $\begin{array}{l}\text { Sub Total } \\
\text { Resection }\end{array}$ & 5 & & 15 & \\
\hline & Biopsy & 3 & & 8 & \\
\hline
\end{tabular}

Table 5: Factors affecting progression free survival and overall survival. *95\% CI at (---) could not be developed due to the sub sample that was too small.

Median overall survival (OS) was better i.e., 16 months in patients who were $<40$ years of age as compared to 14 months in patients $\geq 40$ years of age. There was no difference in the median OS between the two genders in our study. As far as the overall mutations are concerned, they were almost equally present in both the genders and also in patients who were $<40$ or $\geq 40$ years of age (Table 6). Kaplan Meier curves of OS as a function of age and KPS are shown in Figure 1. Kaplan Meier curve of OS and PFS as a function of mutation (D and E) are shown in Figure 2.

\section{Discussion}

Glioblastomas remain one of the most lethal forms of cancers with a median survival of 10 to 12 months [6]. Despite clinical and technological advances in the understanding and treatment of brain tumours over the last three decades, the survival of patients with GBM has not notably improved. Therefore, research focused on the development of new targeted agents and approaches is needed.

A prospective study was undertaken to see the mutational profile of $E G F R$ and PTEN in Glioblastoma multiforme patients in Kashmir and the impact of $E G F R$ inhibitors in combination with surgery and radiotherapy on progression free survival and overall survival of the Glioblastoma multiforme patients in light of EGFR and PTEN mutations.
In the present research study, mutational spectrum of EGFR gene (exon 18, 19, 20 and 21) were studied in 40 confirmed GBM cases. The frequency of mutations in this series aggregated to $32.5 \%$ (13 of 40 ). EGFR mutations in GBM have been extensively studied. In May 2004, two independent groups of investigators reported the discovery of somatic mutations in the TK domain (exons 18-23) of EGFR $[16,17]$. Practically all mutations that have been reported are on exons 18 through 21 . Among all mutations, four predominantly result in TKI drug sensitivity by in vitro and in vivo studies. These include point mutations in exons 18 (G719A/C) and 21 (L858R and L861Q) and inframe deletions in exon 19, which eliminate four amino acids (LREA) downstream of the lysine residue at position 745; other mutations appear to be associated with variable or less sensitivity [16-18].

In the present study, we looked for EGFR mutations in Kashmiri GBM patients. EGFR mutations in GBM were more frequent in men than in women. All the hot spot exons 18-21 were observed to contain the mutations which were of missense in nature. A meta-analysis of nine published studies showed that EGFR mutations are limited to the first four exons (exons 18-21) of the TK domain, which encode the $\mathrm{N}$ lobe and the 5' portion of the alpha C-lobe of EGFR [19]. In our study the mutations were all transversions of two types only which comprised of $07 \mathrm{C}>\mathrm{A}(60 \%)$ and $06 \mathrm{~A}>\mathrm{T}(40 \%)$ involving a range of change in the native amino acids into different amino acids thereby markedly changing the overall structure of the kinase domains of EGFR.

A better understanding of genetics and biology of glioblastoma is critical for development of molecular targeted drugs and rationalization of their delivery to glioblastoma patients whose prognosis remains poor. Indeed, several molecular targeted drugs, particularly antigrowth factor receptors, are already under preclinical or clinical evaluations. Up to now, few patients respond to these drugs [20]. This suggests that other critical gliomagenesis actors remain to be targeted and predictors of response might be precisely identified and validated $[21,22]$. In that way, the present study contributes to a better understanding of glioblastoma genetics, confirming the relatively high frequency of $E G F R$ extracellular domain mutations. Indeed, novel missense mutations of the EGFR extracellular domain have been recently reported in glioblastomas [23-25] and few of our mutations that were detected in GBM patients are consistent to these studies. The $13.5 \%$ rate of missense mutations of the EGFR extracellular domain in our series is in agreement with the findings of Lee et al. [22] but the frequency observed was very less as compared with Lori et al. [24].

Screening of PTEN genes was conducted in a series of $40 \mathrm{GBM}$ samples. The mutations found were only seen in the two hot spot exons (5 and 7) of PTEN and all the mutations that were identified in this study were of missense nature. The overall mutations in both exons in this study aggregated to $17.5 \%$ (07 of 40 ). PTEN mutations have been found in 15 to $40 \%$ of glioblastoma [26,27]. In several previous studies $P T E N$ mutations were not associated with prognosis of glioblastoma $[28,29]$. In our series we report 7 missense mutations mostly in the region of homologous tensin, auxlin and dual specificity phosphatases thereby possibly resulting in the gliomogenesis in the samples harboring these mutations. The frequency of mutations detected in our study, are in tune with the previous studies in GBM $[26,27]$. 
Citation: $\quad$ Arif SH, Pandith AA, Bhat AR, Ramzan AU, Malik Nk,et al. (2015) EGFR and PTEN Gene Mutation Status in Glioblastoma Patients and their Prognostic Impact on Patient's Survival. J Carcinog Mutagen 6: 218. doi:10.4172/2157-2518.1000218

Page 5 of 7

\begin{tabular}{|c|c|c|c|c|c|c|c|c|c|c|c|c|}
\hline & & \multicolumn{2}{|c|}{$\begin{array}{l}\text { EGFR } \\
+\mathrm{ve} / \\
\text { PTEN -ve }\end{array}$} & \multicolumn{2}{|c|}{$\begin{array}{l}P T E N+\mathrm{ve} / \\
E G F R \text {-ve }\end{array}$} & \multicolumn{2}{|c|}{$\begin{array}{l}\text { EGFR+ve/ } \\
P T E N+\mathrm{ve}\end{array}$} & \multicolumn{2}{|c|}{$\begin{array}{l}\text { EGFR-ve/ } \\
P T E N \text {-ve }\end{array}$} & \multicolumn{2}{|c|}{$\begin{array}{l}\text { Overall } \\
\text { Mutations }\end{array}$} & \multirow[t]{2}{*}{$\begin{array}{l}\text { Survival } \\
\text { (months) }\end{array}$} \\
\hline & & $n$ & $\%$ & $n$ & $\%$ & $n$ & $\%$ & $n$ & $\%$ & $n$ & $\%$ & \\
\hline \multirow{2}{*}{$\begin{array}{l}\text { Age } \\
\text { (years) }\end{array}$} & $<40$ & 3 & 42.9 & 0 & 0.0 & 0 & \begin{tabular}{|l|}
0.0 \\
\end{tabular} & 4 & 57.1 & $3 / 7$ & 42.9 & 16 \\
\hline & $\geq 40$ & 7 & 21.2 & 4 & 12.1 & 3 & 9.1 & 19 & 57.6 & $14 / 33$ & 42.4 & 14 \\
\hline \multirow[t]{2}{*}{ Gender } & Male & 8 & 28.6 & 2 & 7.1 & 2 & 7.1 & 16 & 57.1 & $12 / 28$ & 42.9 & 15 \\
\hline & Female & 2 & 16.7 & 2 & 16.7 & 1 & 8.3 & 7 & 58.3 & $5 / 12$ & 41.7 & 15 \\
\hline
\end{tabular}

Table 6: Mutations and survival across age and gender.
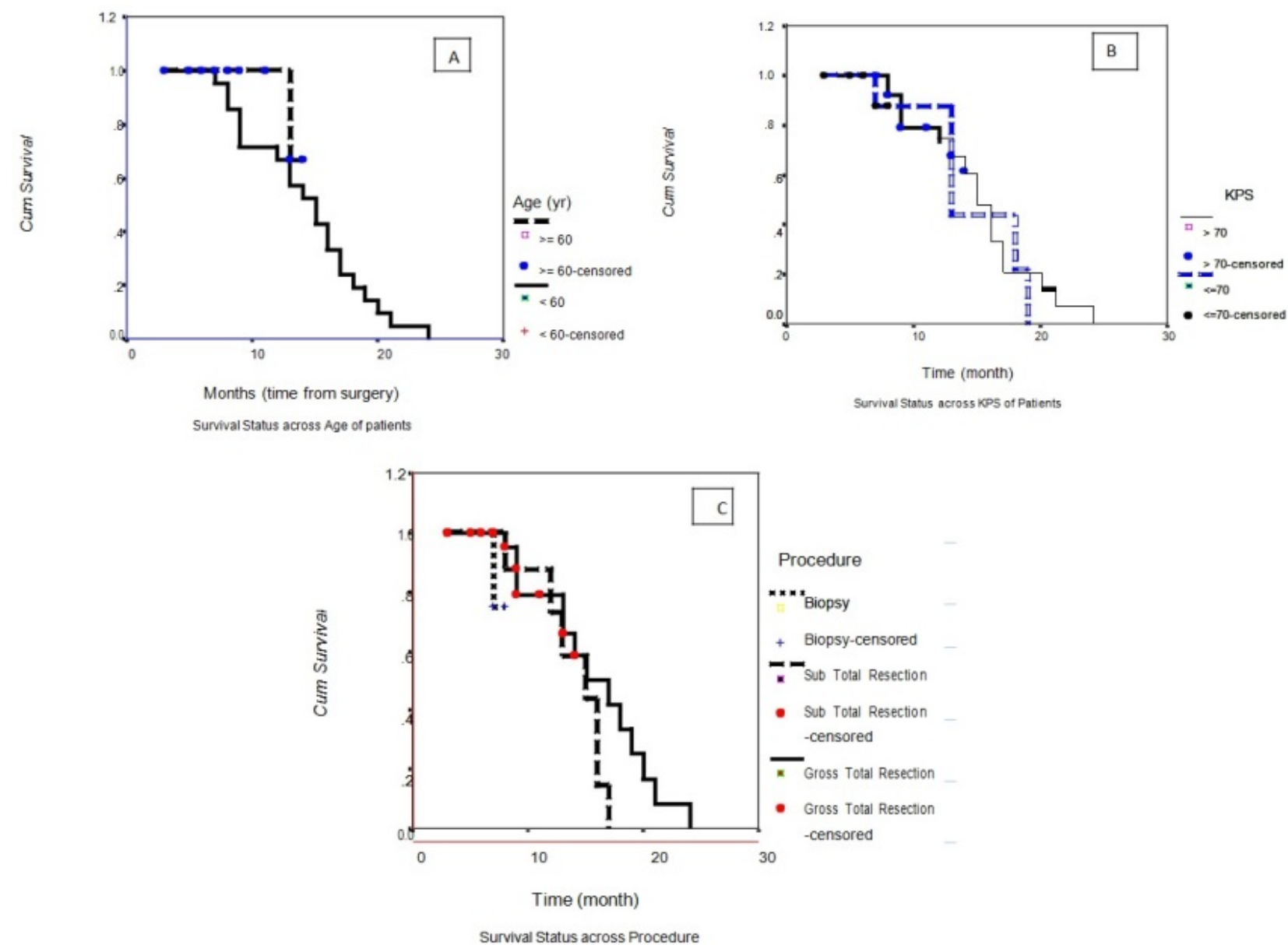

Figure 1: Kaplan Meier curves of OS as a function of age (A) and KPS (B) and procedure (C). 


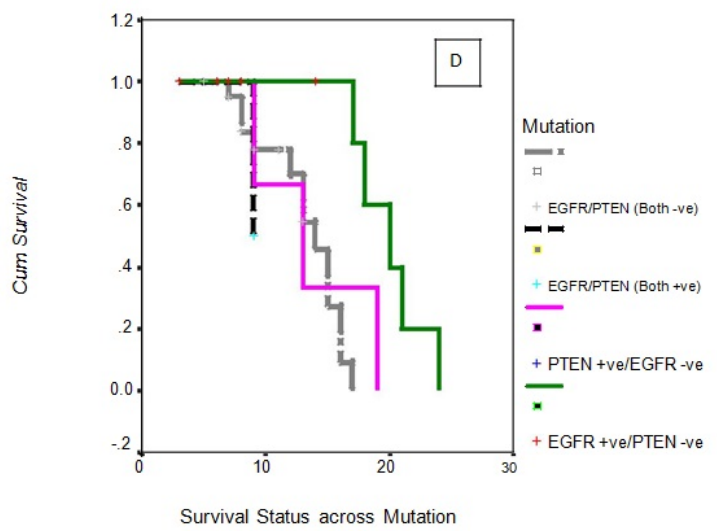

Survival Status across Mutation

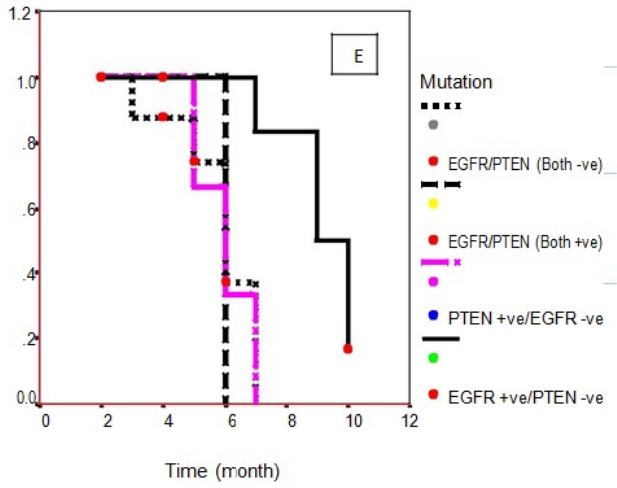

Progression Free Survival across Mutation

Figure 2: Kaplan Meier curve of OS and PFS as a function of mutation (D and E).

Both PTEN and EGFR mutations aggregated to 20 of 40 (50\%) in our series of GBM patients. Though a major proportion of the samples were exclusive for mutations in PTEN and EGFR, but three mutations were commonly found in same samples in both genes and were thus observed to be overlapping in $15 \%$ of the GBM cases. This shows that a good proportion GBM cases harbour both mutations implicating $E G F R$ and PTEN as mutually inclusive genetic events. Our study thus is in agreement with Justin et al., [27] who also observed the same frequency of genetic alterations of EGFR and PTEN in GBM patients.

In our study the overall mutations were almost equally present in both the genders and also in patients who were $<40$ or $\geq 40$ years of age. This is in accordance to Justin S. et al [27] who also observed that there was no association between the incidence of EGFR gene alterations and patient's age but contrary to PTEN alteration that was observed statistically significantly more common among younger patients with GBM [28].

In our study Median Progression free survival (PFS) was 6 months and Median Overall Survival (OS) was 15 months in patients who were $<60$ years of age compared to 14 months in patients $\geq 60$ years of age. Though OS was better in patients $<60$ years of age compared to patients with age $\geq 60$ years $(p>0.05)$. Median PFS could not be calculated in patients with age $\geq 60$ due to the small sample size. Most of the previous studies concluded that patient's age had the greatest effect on survival. Vittorio Donato in 2007 observed that patients under 61 years of age had a significantly prolonged survival [29]. We observed that Median Overall survival was better i.e, 15 months in patients with KPS $>70$ compared to $13(7,19)$ months in patients with KPS $\leq 70(p>0.05)$. Most of the previous studies have also concluded that Median OS is better in patients with good pre-operative KPS $[29,30]$.

Further, we observed median PFS and median OS was better i.e. 9 and 20 months respectively in patients who were $E G F R+\mathrm{ve} / P T E N$-ve as compared to patients with $P T E N+\mathrm{ve} / E G F R$-ve (6 and 13 months), $E G F \mathrm{R}+\mathrm{ve} / P T E N+\mathrm{ve}$ (6 and 9 months) and $E G F R$-ve/PTEN-ve (6 and 14 months) and this association among the mutation pattern was statistically significant $(\mathrm{p}<0.05)$. These observations are in agreement with the previous studies [31-35]. However contrary to our results some of the studies detected no correlation between the outcome and PTEN mutations $[28,36]$.

\section{Conclusion}

We conclude that EGFR and PTEN gene mutations exist in our patients and play a significant role in the development of GBM in Kashmiri population. Moreover, the wild type samples reflect the involvement of different genetic factors, but this needs to be evaluated in further studies in GBM patients in our region.

\section{Acknowledgement}

The authors are grateful to the Head and Technical Staff of the operation theatre of Department of Neuro-Surgery who helped us in the tissue procurement of GBM patients. We also thank the anonymous pathologists of Department of Pathology for the histopathological assessment of the tumor tissues.

\section{References}

1. Grossman SA, Batara JF (2004) Current management of glioblastoma multiforme. Semin Oncol 31: 635-644.

2. Uddin ABMS, Jarmi T. Neurologic Manifestations of Glioblastoma Multiforme. Medscape Drugs and Diseases.

3. Ries LAG, Eisner MP, Kosary CL (2001) SEER Cancer Statistics, 1973-1998. Bethesda.

4. Buckner JC (2003) Factors influencing survival in high-grade gliomas. Semin Oncol 30: 10-14.

5. Abdul RB, Altaf K, Tariq HR, Wani MA, Ramzan AU, et al. (2008) Analysis of Surgical outcome of brain tumors in Kashmir-A 26 year experience at SKIMS. Journal of Medical Sciences 11: 152-158.

6. Legler JM, Ries LAG, Smith MA, Warren JL, Heineman EF, et al. (1999) Brain and other central nervous system cancers: recent trends in incidence and mortality. J Natl Cancer Inst. 91: 1382-1390.

7. Giese A, Bjerkvig R, Berens ME, Westphal M (2003) Cost of migration: invasion of malignant gliomas and implications for treatment. J Clin Oncol 21: 1624-1636.

8. Kesari S, Ramakrishna N, Sauvageot C, Stiles CD, Wen PY (2005) Targeted molecular therapy of malignant gliomas. Curr Neurol Neurosci Rep 5: 186-197. 
Citation: Arif SH, Pandith AA, Bhat AR, Ramzan AU, Malik Nk,et al. (2015) EGFR and PTEN Gene Mutation Status in Glioblastoma Patients and their Prognostic Impact on Patient's Survival. J Carcinog Mutagen 6: 218. doi:10.4172/2157-2518.1000218

Page 7 of 7

9. Chakravarti A, Dicker A, Mehta M (2004) The contribution of epidermal growth factor receptor (EGFR) signaling pathway to radioresistance in human gliomas: a review of preclinical and correlative clinical data. Int J Radiat Oncol Biol Phys 58: 927-931.

10. Lee JC, Vivanco I, Beroukhim R, Huang JH, Feng WL, et al. (2006) Epidermal growth factor receptor activation in glioblastoma through novel missense mutations in the extracellular domain. PLoS Med 3: e485.

11. Hatanpaa KJ, Burma S, Zhao D, Habib AA (2010) Epidermal growth factor receptor in glioma: signal transduction, neuropathology, imaging, and radioresistance. Neoplasia 12: 675-684.

12. Wang SI, Puc J, Li J, Bruce JN, Cairns P, et al. (1997) Somatic mutations of PTEN in glioblastoma multiforme. Cancer Res 57: 4183-4186.

13. Yang Y, Shao N, Luo G, Li L, Zheng L, et al. (2010) Mutations of PTEN gene in gliomas correlate to tumor differentiation and short-term survival rate. Anticancer Res 30: 981-985.

14. U.S. Food and Drug Administration. Center for Drug Evaluation and Research (2006) Guidance for industry clinical trial endpoints for the approval of cancer drugs and biologics.

15. Macdonald DR, Cascino TL, Schold SC Jr, Cairncross JG (1990) Response criteria for phase II studies of supratentorial malignant glioma. J Clin Oncol 8: 1277-1280.

16. Eberhard DA, Johnson BE, Amler LC, Goddard AD, Heldens SL, et al. (2005) Mutations in the epidermal growth factor receptor and in KRAS are predictive and prognostic indicators in patients with non-small-cell lung cancer treated with chemotherapy alone and in combination with erlotinib. J Clin Oncol 23: 5900-5909.

17. Chen YR, Fu YN, Lin CH, Yang ST, Hu SF, et al. (2006) Distinctive activation patterns in constitutively active and gefitinib-sensitive EGFR mutants. Oncogene 25: 1205-1215.

18. Sharma SV, Bell DW, Settleman J, Haber DA (2007) Epidermal growth factor receptor mutations in lung cancer. Nat Rev Cancer 7: 169-181.

19. Shigematsu H, Gazdar AF (2006) Somatic mutations of epidermal growth factor receptor signaling pathway in lung cancers. Int J Cancer 118: 257-262.

20. Tokumo M, Toyooka S, Kiura K, Shigematsu H, Tomii K, et al. (2005) The relationship between epidermal growth factor receptor mutations and clinicopathologic features in non-small cell lung cancers. Clin Cancer Res 11: 1167-1173.

21. Soung YH, Lee JW, Kim SY, Seo SH, Park WS, et al. (2005) Mutational analysis of EGFR and K-RAS genes in lung adenocarcinomas. Virchows Arch 446: 483-488.

22. Lee JC, Vivanco I, Beroukhim R, Huang JH, Feng WL, et al. (2006) Epidermal growth factor receptor activation in glioblastoma through novel missense mutations in the extracellular domain. PLoS Med 3: e485.

23. Arjona D, Bello MJ, Alonso ME, Aminoso C, Isla A, et al. (2005) Molecular analysis of the EGFR gene in astrocytic gliomas: mRNA expression, quantitative-PCR analysis of non-homogeneous gene amplification and DNA sequence alterations. Neuropathol Appl Neurobiol 31: 384-94.

24. Frederick L, Wang XY, Eley G, James CD (2000) Diversity and frequency of epidermal growth factor receptor mutations in human glioblastomas. Cancer Res 60: 1383-1387.

25. Simpson L, Parsons R (2001) PTEN: life as a tumor suppressor. Exp Cell Res 264: 29-41.

26. Knobbe CB, Merlo A, Reifenberger G (2002) Pten signaling in gliomas. Neuro Oncol 4: 196-211.

27. Smith JS, Tachibana I, Passe SM, Huntley BK, Borell TJ, et al. (2001) PTEN mutation, EGFR amplification, and outcome in patients with anaplastic astrocytoma and glioblastoma multiforme. J Natl Cancer Inst 93: 1246-1256.

28. Schmidt MC, Antweiler S, Urban N, Mueller W, Kuklik A, et al. (2002) Impact of genotype and morphology on the prognosis of glioblastoma. J Neuropathol Exp Neurol 61: 321-328.

29. Donato V, Papaleo A, Castrichino A, Banelli E, Giangaspero F, et al (2007) Prognostic implication of clinical and pathological features in patients with glioblastoma multiforme treated with concomitant radiation plus temozolomide. Tumori 93: 248-256.

30. Weller M, Felsberg J, Hartmann C, Berger H, Steinbach JP, et al. (2009) Molecular Predictors of Progression-Free and Overall Survival in Patients with Newly Diagnosed Glioblastoma: A Prospective Translational Study of the German Glioma Network. J Clin Oncol 27: 5743-5750.

31. Mellinghoff IK, Wang MY, Vivanco I, Haas-Kogan DA, Zhu S, et al. (2005) Molecular determinants of the response of glioblastomas to EGFR kinase inhibitors. N Engl J Med 353: 2012-2024.

32. Sordella R, Bell DW, Haber DA, Settleman J (2004) Gefitinib-sensitizing EGFR mutations in lung cancer activate anti-apoptotic pathways. Science 305: 1163-1167.

33. Choe G, Horvath S, Cloughesy TF, Crosby K, Seligson D, et al. (2003) Analysis of the phosphatidylinositol 3'-kinase signaling pathway in glioblastoma patients in vivo. Cancer Res 63: 2742-2746.

34. Li B, Yuan M, Kim IA, Chang CM, Bernhard EJ, et al. (2004) Mutant epidermal growth factor receptor displays increased signalling through the phosphatidylinositol-3 kinase/AKT pathway and promotes radioresistance in cells of astrocytic origin. Oncogene 23: 4594-602.

35. Huang HS, Nagane M, Klingbeil CK, Lin H, Nishikawa R, et al. (1997) The enhanced tumorigenic activity of a mutant epidermal growth factor receptor common in human cancers is mediated by threshold levels of constitutive tyrosine phosphorylation and unattenuated signalling. J Biol Chem 272: 2927-2935.

36. Zhou XP, Sanson M, Hoang-Xuan K, Robin E, Taillandier L, et al. (1999) Germline mutations of p53 but not p16/CDKN2 or PTEN/MMAC1 tumor suppressor genes predispose to gliomas. The ANOCEF Group. Association des NeuroOncologues d'Expression Française. Ann Neurol 46: 913-916. 